\title{
Dipyrithione induces cell-cycle arrest and apoptosis in four cancer cell lines in vitro and inhibits tumor growth in a mouse model
}

\author{
Yumei Fan', Caizhi Liu', Yongmao Huang ${ }^{2}$, Jie Zhang ${ }^{1}$, Linlin Cai', Shengnan Wang ${ }^{1}$, Yongze Zhang ${ }^{1}$, \\ Xianglin Duan ${ }^{1 *}$ and Zhimin Yin ${ }^{3^{*}}$
}

\begin{abstract}
Background: Dipyrithione (PTS2) is widely used as a bactericide and fungicide. Here, we investigated whether PTS2 has broad-spectrum antitumor activity by studying its cytotoxicity and proapoptotic effects in four cancer cell lines.

Methods: We used MTT assays and trypan blue staining to test the viability of cancer cell lines. Hoechst 33258 and DAPI staining were used to observe cell apoptosis. Cell-cycle percentages were analyzed by flow cytometry. Apoptosis was assayed using caspase-3 and poly (ADP-ribose) polymerase (PARP) combined with Western blotting. Student's t-test was used for statistical analysis.

Results: PTS2 inhibited proliferation in four cancer cell lines in a dose-dependent manner. Treated cells showed shrinkage, irregular fragments, condensed and dispersed blue fluorescent particles compared with control cells. PTS2 induced cycle-arrest and death. Cleavage of caspase-9, caspase-3, and PARP were detected in PTS2-treated cells. Antitumor activity of PTS2 was more effective against widely used cancer drugs and its precursor.
\end{abstract}

Conclusions: PTS2 appears to have novel cytotoxicity and potent broad-spectrum antitumor activity, which suggests its potential as the basis of an anticancer drug.

Keywords: PTS2, Anti-tumor activity, Chemotherapy

\section{Background}

Apoptosis is a cellular progression characterized by a series of tightly regulated molecular processes leading to cell death [1]. There are two independent apoptosis pathways: the death receptor pathway and the mitochondria pathway [2], both of which converge on a family of cysteine aspartases called caspases, whose activity drives the biochemical events leading to cellular disassembly and death. Novel second mitochondria-derived activator of caspases (Smac) mimetic compounds sensitize human leukemia cell lines to conventional chemotherapies that induce death receptor-mediated apoptosis [3,4]. During apoptosis, cytochrome $c$, a component of the mitochondrial electron

\footnotetext{
* Correspondence: xlduan0311@163.com; yinzhimin@njnu.edu.cn

${ }^{1}$ The Key Lab of Animal Physiology, College of Life Science, Hebei Normal University, Hebei Province, Shijiazhuang 050024, China

${ }^{3}$ Jiangsu Province Key Laboratory of Molecular and Medical Biotechnology, College of Life Science, Nanjing Normal University, Nanjing 210046, China Full list of author information is available at the end of the article
}

transfer chain, releases from mitochondria to the cytosol, and binds to Apaf-1, a cytosolic protein, forming the Apaf$1 /$ cytochrome $c$ complex, which then oligomerizes and forms apoptosomes by recruiting multiple procaspase- 9 molecules, and then cleaving and activating downstream apoptosis effectors such as caspase-3, and PARP [5]. As malignancies grow, cancer cells evolve around mechanisms that limit cell proliferation, such as apoptosis and replicative senescence. Successful cancer therapies may trigger tumor-selective apoptosis [6].

Pyrithione (2-pyridinethiol-1-oxide, PT) has been used as a bactericide and fungicide for more than 50 years [7]. PT derivatives, such as zinc PT and sodium PT, are widely used as cosmetic preservatives and as anti-dandruff agents in shampoos. Zinc PT can reportedly induce apoptosis because of its role as a zinc-ionophore $[8,9]$. Compounds containing -SH group are quickly oxidized to generate disulfide. For PT, such self-oxidation would result in the formation of the dimer, 2,2'-dithiobispyridine-1,1'-dioxide 
(dipyrithione, PTS2; Figure 1), which also possesses antibacterial and anti-fungal activity. Our previous study demonstrated the cytotoxicity and effect of PTS2 in HeLa cells [4], and PTS2 inhibited inflammatory responses induced by lipopolysaccharides (LPS) in RAW264.7 cells, thus protecting mice against endotoxic shock by exerting antiinflammatory effects through decreased formation of chemokine IP-10/CXCL10 and reduced acute oleic acidinduced lung injury [10-12].

Here we reported novel toxicity, including inhibited proliferation and induced apoptosis, of PTS2 in four cancer cell lines. Our results indicated that PTS2 has broadspectrum antitumor activity, suggesting its potential as the basis of an anticancer drug.

\section{Methods}

\section{Cell culture}

MDA-MB-231 (human breast cancer cell line), KB (nasopharyngeal carcinoma cell line), U937 (human monoblast leukemia cell line), and K562 (human leukemia cell line) were purchased from the CBCAS (Cell Bank of the Chinese Academic of Sciences, Shanghai, China). Cells were maintained in RPMI1640 (GIBCO), supplemented with $10 \%(\mathrm{v} / \mathrm{v})$ fetal bovine serum (HyClone), sodium bicarbonate, $100 \mu \mathrm{g} / \mathrm{ml}$ streptomycin and $100 \mathrm{U} / \mathrm{ml}$ penicillin (HyClone) at $37^{\circ} \mathrm{C}$, in a humidified $5 \% \mathrm{CO}_{2}$ atmosphere.

\section{Antibodies and reagents}

PTS2 and PT were purchased from J\&K Chemical LTD. Adriamycin (ADM) was purchased from Hisun (Zhejiang Hisun Pharceutical Co., LTD). Cisplatin (DDP) was purchased from QiLu (QiLu Pharmaceutical Co., LTD.). MTT, Hoechst33258, DAPI and propidium iodide (PI) were from Sigma (Sigma Chemical Co., St Louis, MO). Antibodies to caspase-3, PARP, CyclinD1, CyclinE1 and caspase-9 were purchased from Cell Signaling Technology (Beverly, MA). Antibodies to p21 were purchased from Santa Cruz Biotechnology (Santa Cruz, CA). All chemicals and drugs were prepared in PBS immediately before use.

\section{Western blotting}

Western blotting was performed as described previously [13]. Cells were washed twice with ice-cold PBS (pH 7.4) and lysed in a lysis buffer containing $50 \mathrm{mM}$ Tris$\mathrm{HCl}(\mathrm{pH} 8.0), 150 \mathrm{mM} \mathrm{NaCl}, 0.5 \mathrm{mM}$ dithiothreitol, $1 \mathrm{mM}$ EDTA, 1\% NP-40, 10\% (v/v) glycerol, $50 \mu \mathrm{g} / \mathrm{ml}$ phenylmethylsulfonyl fluoride, $2 \mu \mathrm{g} / \mathrm{ml}$ aprotinin, $1 \mu \mathrm{g} / \mathrm{ml}$ leupeptin, $1 \mu \mathrm{g} / \mathrm{ml}$ pepstatin and $1 \mathrm{mM} \mathrm{Na}_{3} \mathrm{VO}_{4}$. After incubation on ice for $20 \mathrm{~min}$, lysates were centrifuged at $15,000 \times \mathrm{g}$ for $10 \mathrm{~min}$ at $4^{\circ} \mathrm{C}$ and the supernatant was transferred to a clean microfuge tube. Equal amounts of the soluble protein were denatured in SDS, electrophoresed on SDS-polyacrylamide gel, and transferred to a PVDF membrane. Horseradish peroxidase (HRP)-conjugated goat anti-rabbit IgG antibodies were used against respective primary antibodies. Proteins were visualized using Lumi-Light Western Blotting Substrate (Roche Molecular Biochemicals). The total density of the protein bands was calculated using the Scion Image software program (Scion Corp., Frederick, MD).

\section{Cell proliferation assay}

Cells were seeded into 96 -well plates at $5 \times 10^{3}$ cells per well $24 \mathrm{~h}$ before treatment. After treatment with different drugs, cell proliferation was determined using MTT (3-(4,5 dimethylthiazol-2-yl)-2,5-diphenyltetrazolium bromide) assay. Briefly, $15 \mu \mathrm{l}(5 \mathrm{mg} / \mathrm{ml})$ MTT solution was added to each well, and incubated at $37^{\circ} \mathrm{C}$ for $4 \mathrm{~h}$, after which the MTT solution was removed and $200 \mu \mathrm{l}$ of dimethylsulfoxide (DMSO) added to dissolve the crystals. Absorbance of each well was measured at $570 \mathrm{~nm}$ using an ELx 800 Universal Microplate Reader (Bio-Tek, Inc.) according to manufacturer's instructions.

\section{Trypan blue assay}

Cells were seeded in 6-well culture plates. After $24 \mathrm{~h}$, culture medium containing $2.5 \mu \mathrm{g} / \mathrm{ml}$ of PTS2 was added to the wells. Cells were harvested at indicated times and washed with PBS, followed by centrifugation at $2500 \mathrm{~g}$ for $5 \mathrm{~min}$. The cell pellet was then resuspended in $1 \mathrm{ml}$ of fresh culture medium; $10 \mu \mathrm{l}$ of the cell suspension was stained with an equal volume of trypan blue (Sigma, Germany) and incubated for $2 \mathrm{~min}$ at $37^{\circ} \mathrm{C}$. The total number of viable cells was estimated using a hemocytometer chamber.

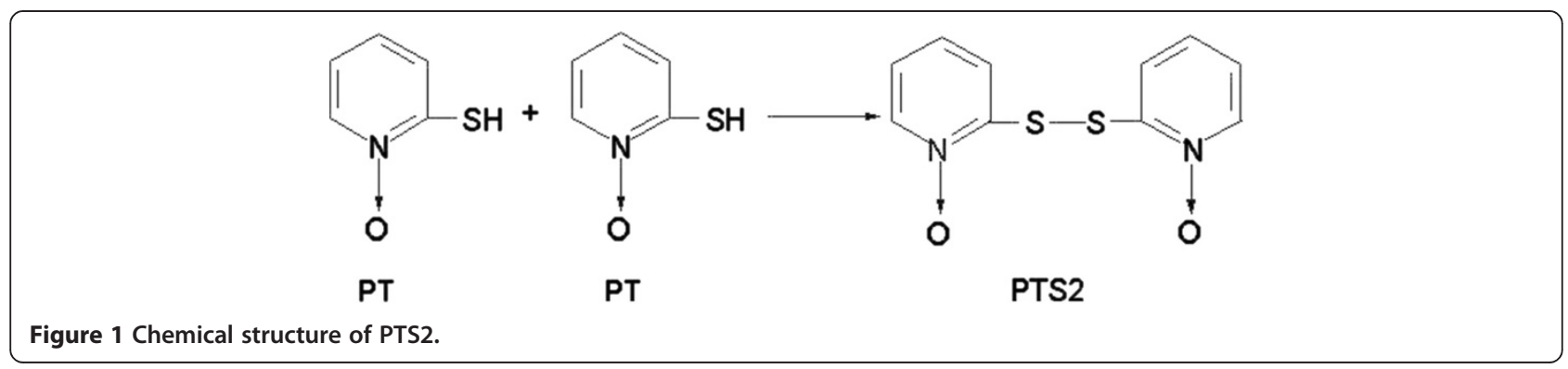




\section{Hoechst33258 Staining}

A staining solution of Hoechst33258 was prepared immediately before use. After drug treatment, cells were collected and fixed in acetic acid/methanol (1:3) solution for $5 \mathrm{~min}$ at $4^{\circ} \mathrm{C}$, washed 3 times with PBS, and then incubated with Hoechst $33258(50 \mathrm{ng} / \mathrm{ml}$ ) for $5 \mathrm{~min}$ and washed 3 times with PBS. Cells were then assessed for Hoechst fluorescence in a Nikon Optiphot fluorescence microscope (magnification: $\times 400$ ).

\section{DAPI staining}

Cells for 4'-6-diamidino-2-phenylindole (DAPI) staining underwent the same PTS2 treatment as those stained with Hoechst33258. Collected cells were fixed with acetic acid/methanol (1:3) solution for $10 \mathrm{~min}$ at room temperature and then incubated in DAPI $(1 \mu \mathrm{g} / \mathrm{ml})$ for 5 min. After being washed 3 times with PBS, cells were examined using a Nikon Optiphot fluorescence microscope (magnification: $\times 400$ ).

\section{Cell cycle analysis}

Cell cycle distribution was analyzed by flow cytometry. Control and treated cells were harvested, washed twice with PBS, and fixed in $70 \%$ ethanol overnight at $-20^{\circ} \mathrm{C}$. Fixed cells were washed twice with PBS, incubated with $1 \mathrm{ml}$ of PBS containing $50 \mu \mathrm{g} / \mathrm{ml}$ propidium iodide, $100 \mu \mathrm{g} / \mathrm{ml}$ RNase A and $0.1 \%$ Triton X-100 for $30 \mathrm{~min}$ at $37^{\circ} \mathrm{C}$. Stained cells were analyzed using a FAScan laser flow cytometer (Becton Dickinson) and ModFit LT cell cycle analysis software (Verity Software).

\section{Apoptosis assay}

Apoptosis was determined using Annexin V-FITC/ PI double staining. After treatment, floating and adherent cells were collected, washed twice with PBS ( $\mathrm{pH} 7.4)$, resuspended in $150 \mu \mathrm{l}$ of Annexin-binding buffer and incubated with $0.4 \mu \mathrm{l}$ of Annexin V-FITC. After $20 \mathrm{~min}$ incubation in the dark at room temperature, $150 \mu \mathrm{l}$ of Annexin-binding buffer with $3 \mu \mathrm{l}$ of PI $(50 \mu \mathrm{g} / \mathrm{ml})$ was added just before flow cytometry. Data were analyzed by flow cytometry using the FACSCalibur and Cell Quest software (Becton Dickinson).

\section{Animals and solid tumor models}

All experiments followed the recommendations of the Chinese Experimental Animals Administration Legislation, as approved by the Science and Technology Department of Jiangsu Province. Male ICR mice (6 weeks old, 18-20 g) purchased from Shanghai Laboratory Animal Center, Chinese Academy Sciences, were kept in groups of five animals per cage in a temperature-controlled room at $20 \pm 2^{\circ} \mathrm{C}$. They were fed a standard pellet diet and water ad libitum. As described in [4], two groups of 40 animals each were transplanted subcutaneously with hepatoma $22(\mathrm{H} 22)$ tumor cells $\left(5 \times 10^{6}\right.$ cells $\left./ \mathrm{ml}\right)$ in $0.2 \mathrm{ml} \mathrm{PBS}$ into their right groins. At $24 \mathrm{~h}$ after tumor inoculation, each set of 40 mice was randomly divided into 4 groups (10 mice per group) and injected intraperitoneally with PTS2 ( 0.25 or $2.5 \mathrm{mg} / \mathrm{kg} /$ day), DDP $(25 \mathrm{mg} / \mathrm{kg} /$ day) or $0.2 \mathrm{ml} 0.9 \%$ saline for a further 10 days. On day 11 , all the animals were killed, and the tumors were dissected and weighed. Tumor growth inhibition was calculated using the formula:\% inhibition $=100 \times([\mathrm{C}-\mathrm{T}] / \mathrm{C})$, where $\mathrm{C}$ is the average tumor weight of the control group and $\mathrm{T}$ is the average tumor weight of each treated group.

\section{Statistics}

Statistical analysis used SPSS 12.0 (SPSS, Chicago, IL, USA). Results are expressed as means \pm S.D. Differences between means were determined by one-way ANOVA, followed by Student-Newman-Keuls tests for multiple comparisons and Student's $t$ test for other data. $P<0.05$ was considered statistically significant.

\section{Results}

\section{PTS2 decreases cancer cell viability}

To assess effects of PTS2 on cancer cell growth or proliferation, 4 cancer cell lines, including KB, 231, U937 and K562, were assayed using MTT. After $36 \mathrm{~h}$ treatment with various concentrations of PTS2, cell viability was determined for all 4 cell lines. PTS2 $(0.25-5 \mu \mathrm{g} / \mathrm{ml})$ was found to decrease cell viability in a dose-dependent manner (Figure 2A). The effect of PTS2 on cell proliferation was also examined. Results showed that PTS2 significantly decreased cell numbers in all 4 cancer cell lines compared with controls, as assessed using trypan blue (Figure 2B). These data indicate that PTS2 can decrease cell viability or proliferation within a suitable concentration range.

\section{PTS2 induces cell cycle arrest in cancer cells}

Cell proliferation is well correlated to regulation of cell cycle progression. A common mechanism for chemotherapeutic drugs is blocking passage through the $G_{1}$ phase of the cell cycle [14]. We therefore investigated whether PTS2 can cause $G_{1}$ cell cycle arrest in treated cancer cells (Figure 3). Cells exposed to PTS2 at $2.5 \mu \mathrm{g} / \mathrm{ml}$ for $24 \mathrm{~h}$ showed a marked increase in the percentage in $G_{1}$ phase, and concomitant decreases in $S$ phase and $G_{2}$ phase populations, compared with vehicle-treated controls (Figure 3A).

As p21 ${ }^{\mathrm{WAF} 1 / \mathrm{Cip} 1}$ (p21) inhibits the cell cycle through its interaction with cyclin-CDK complexes [15], and is induced by $\mathrm{p} 53$ in response to DNA damage resulting in CDK inhibition and $G_{1}$ growth arrest [16]. We further tested the effect of PTS2 on endogenous p53, p21, CyclinD1 and CyclinE1 expression in the four cancer cell lines. After cells were treated with PTS2 $(2.5 \mu \mathrm{g} / \mathrm{ml})$ for 


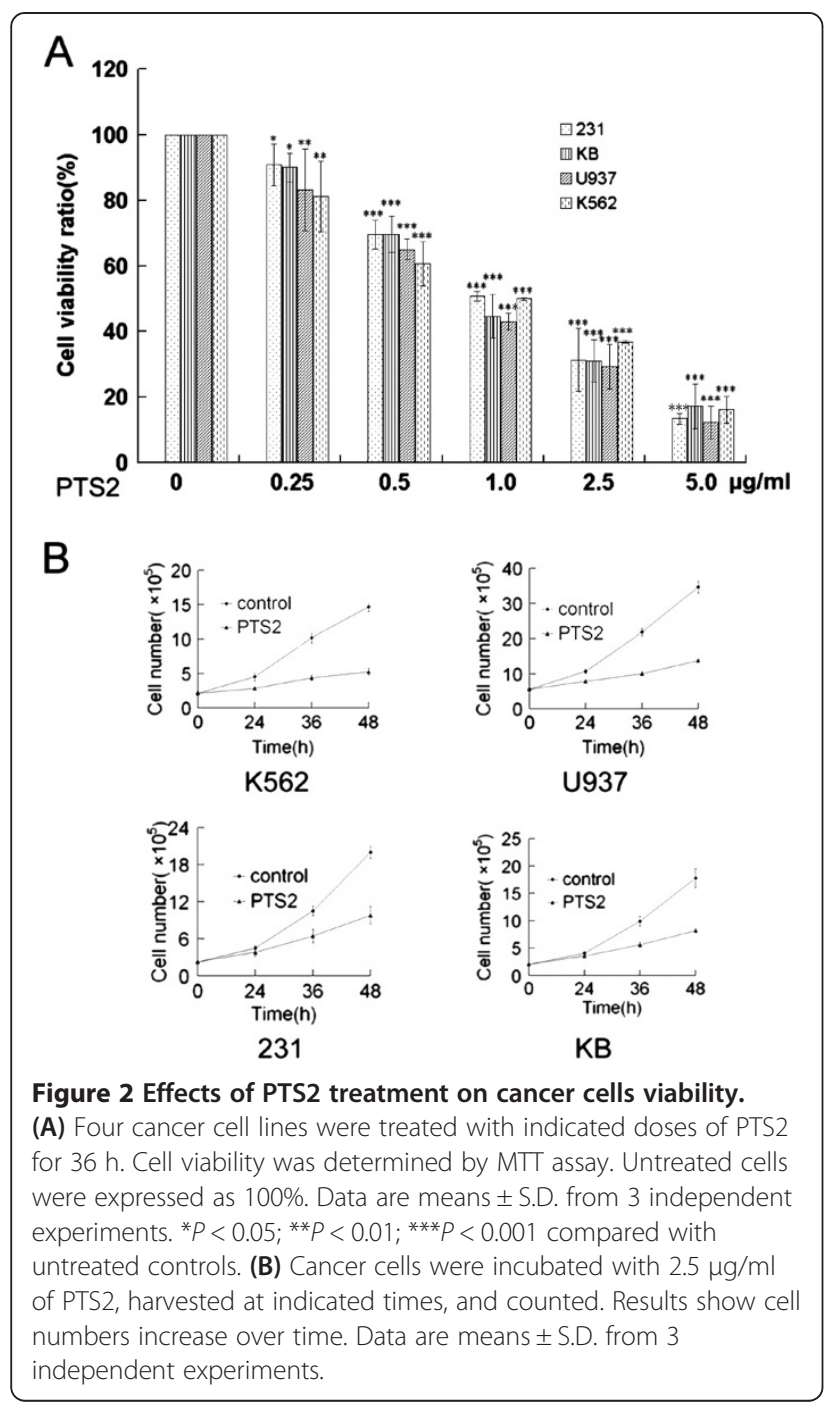

$24 \mathrm{~h}$, PTS2 induced p21 accumulation in all cells as shown by Western blot (Figure 3B). CyclinD1 and CyclinE1 expressions were downregulated. These results were in accordance with the cell cycle experiment and previous reports $[17,18]$, and suggest that PTS2-induced $\mathrm{G}_{1}$ arrest in cancer cells could be mediated via modulation of p53, p21, CyclinD1 and CyclinE1 levels.

\section{PTS2 induces cancer cell apoptosis}

Morphology alteration and chromatin condensation are two indicators of cell apoptosis. To verify whether the growth inhibitory effect of PTS2 was due to apoptosis, KB, 231, U937 and K562 cells were treated with PTS2 at $2.5 \mu \mathrm{g} / \mathrm{ml}$ for $36 \mathrm{~h}$, and then observed under a light microscope or under a fluorescence microscope after Hoechst33258 and DAPI staining. We found the PTS2treated cells were shrunken, with irregular fragments and apoptotic bodies, in contrast to control cells (Figure 4A). The typical apoptosis appearance, including condensed and dispersed or fragmented blue fluorescent particles was observed in PTS2-treated cells compared with control cells (Figure 4B, C), which suggests that PTS2 induces apoptosis in these types of cancer cells obviously.

\section{PTS2 induced cleavage of caspase-9, caspase-3 and PARP}

Caspase family members, including caspase- 9 and caspase-3, as well as downstream substrates such as PARP, are crucial mediators of the apoptotic process. To see whether PTS2-induced cell death involved activation of caspases and PARP, we analyzed cleavage of caspase-9, caspase-3 and PARP in PTS2-treated cancer cells. Cells were incubated with $2.5 \mu \mathrm{g} / \mathrm{ml}$ of PTS2 for $36 \mathrm{~h}$. As expected, Western blot results showed that caspase-9, caspase- 3 and PARP were cleaved (Figure 5). Activation of caspases and PARP thereby confirmed apoptosis. This suggests that cleavage of caspase-9, caspase-3 and PARP are involved in PTS2-induced cancer cell apoptosis.

\section{PTS2 is more effective to induce cancer cell apoptosis against DDP, ADM or PT}

Adriamycin (ADM) and cisplatin (DDP) are widely used cancer drugs. To further evaluate the efficacy of PTS2 in decreasing cancer cell viability, we compared its effects on $\mathrm{KB}$ cells to those of ADM and DDP. KB cells were exposed to $2.5 \mu \mathrm{g} / \mathrm{ml}$ of PTS2, ADM or DDP and assayed with MTT. At 3-36 h after treatment, PTS2 also showed faster results than did ADM or DDP (Figure 6A). In the dose range of $0.25-5.0 \mu \mathrm{g} / \mathrm{ml}$, PTS2 was more effective in inhibiting cell viability than was ADM or DDP, although PT, the precursor of PTS2, exerted no obvious effect (Figure 6B). Flow cytometry analysis showed $2.5 \mu \mathrm{g} / \mathrm{ml}$ of PTS2 to be more effective in killing KB cell than PT and DDP (Figure 6C). These results strongly suggest that PTS2 can induce cancer cell death at least as efficiently as current anti-tumor drugs.

\section{PTS2 inhibits tumor growth}

To see effects of PTS2 on murine solid tumors, hepatoma $22(\mathrm{H} 22)$ cells $\left(5 \times 10^{6}\right.$ cells $\left./ \mathrm{ml}\right)$ were transplanted subcutaneously into the right groins of mice; $24 \mathrm{~h}$ after tumor implantation, the mice were injected intraperitoneally with PTS2, DDP or saline and observed for 10 days. PTS2 at $2.5 \mathrm{mg} / \mathrm{kg} /$ day reduced the weight of H22 tumors; DDP had a similar effect at $25 \mathrm{mg} / \mathrm{kg} /$ day (Figure 7A). The tumor growth inhibition rate of PTS2 $(2.5 \mathrm{mg} / \mathrm{kg} /$ day $)$ was more effective than DDP $(25 \mathrm{mg} /$ $\mathrm{kg} /$ day) (Figure 7B). Moreover, the body weight increase of the PTS2-treated mice was greater than that of the DDP-treated mice (data not shown).

\section{Discussion}

PTS2, a compound related to pyridinethione, has been used as a bactericide, pesticide and fungicide for a long 

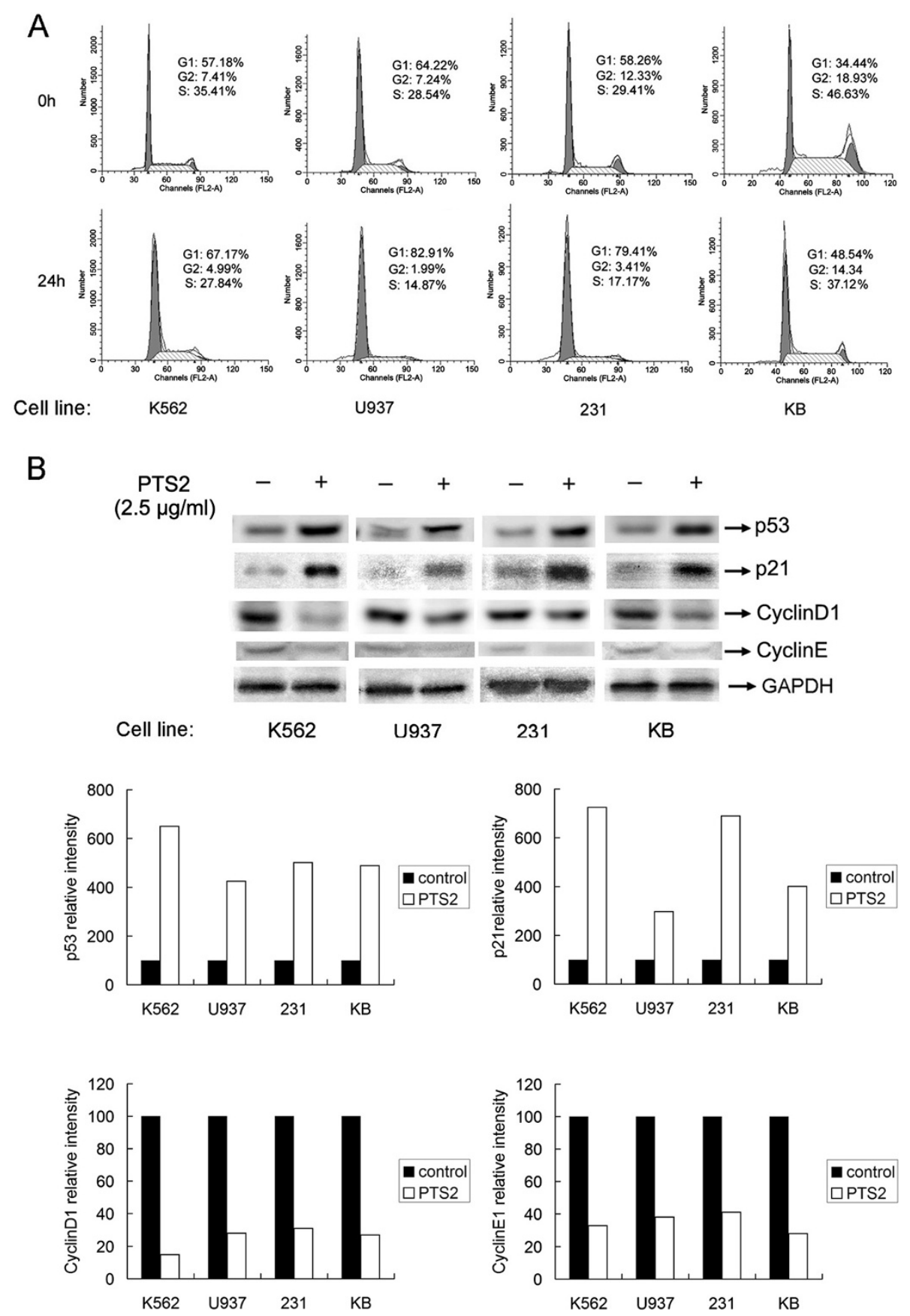

Figure 3 PTS2 induces cell cycle arrest in cancer cells. (A) Cancer cells were incubated with PTS2 $(2.5 \mu \mathrm{g} / \mathrm{ml})$ for $24 \mathrm{~h}$, harvested and stained with propidium iodide (PI). Nuclei fluorescence was measured. Percentages of cells in each cell cycle phase are also shown. Results are representative of 3 independent experiments. (B) Cells were incubated with PTS2 $(2.5 \mu \mathrm{g} / \mathrm{ml})$ for $24 \mathrm{~h}$, and then harvested. Western blot was performed using antibodies to p53, p21, CyclinD1, CyclinE1 and GAPDH. Results represent three independent experiments.

time. Our previous report showed that PTS2 exerted cytotoxicity on HeLa cells and reduced the weight of S180 and H22 tumors [4]. The goal of the present study was to explore the cytotoxicity of PTS2 in other cancer cell lines and assess its potential broad-spectrum antitumor activity. We found PTS2 induced cell death in four cancer cell lines in vitro, and decreased viability in these cell lines in a dose-dependent manner (Figure 2). At a dose of $2.5 \mu \mathrm{g} /$ $\mathrm{ml}$, PTS2 induced apoptosis in various cancer cell lines, as detected by morphological and fluorescence analysis (Figure 4), thus raising the possibility that capsaicin might be a potential chemopreventive or therapeutic agent. 

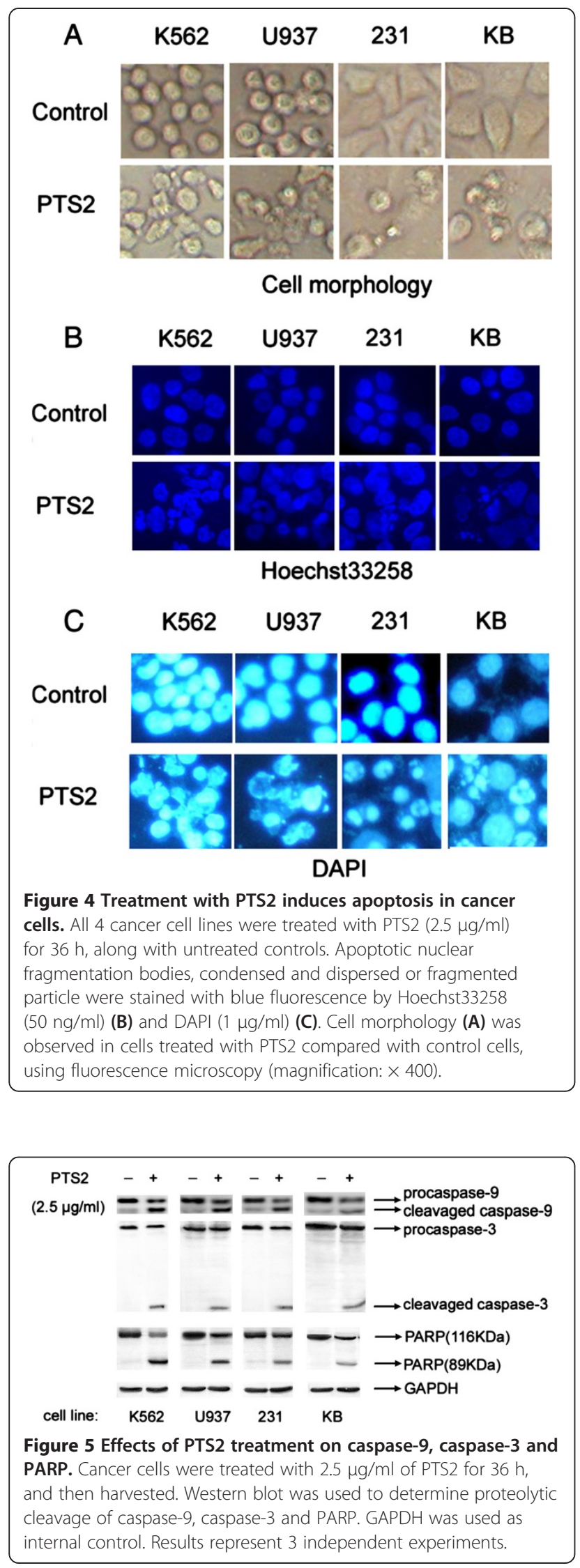

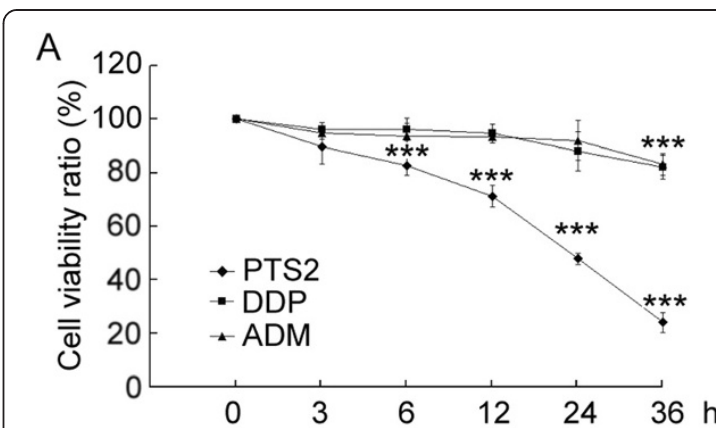

B

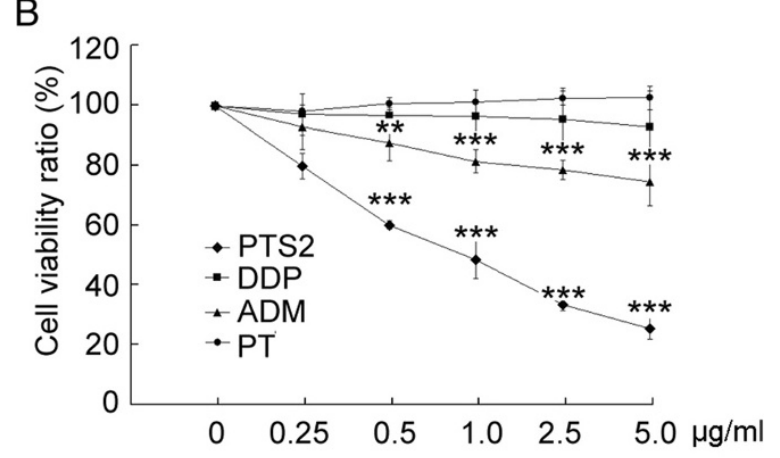

C

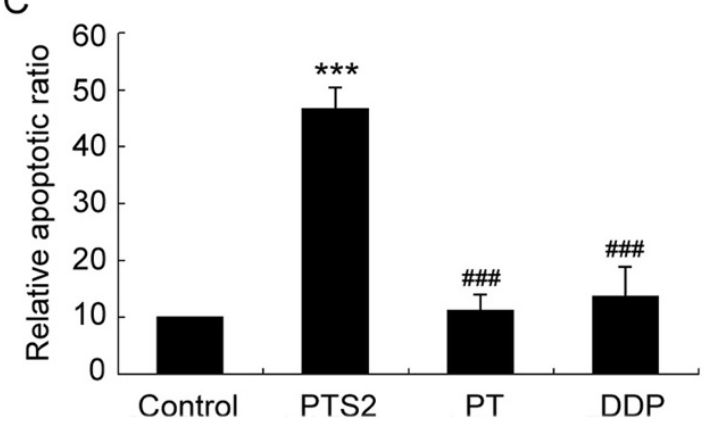

Figure 6 Comparison of effects of PTS2, PT, DDP and ADM on KB cell viability. (A) PTS2, PT, DDP and ADM $(2.5 \mu \mathrm{g} / \mathrm{ml})$ were added to KB cells, and assayed using MTT to determine cell viability after incubation for the indicated times. (B) In KB cells exposed to the indicated amounts of PTS2, PT, DDP and ADM for $36 \mathrm{~h}$, cell viability was assayed using MTT. Data are means \pm S.D. from 3 independent experiments. ${ }^{*} P<0.01 ;{ }^{* *} P<0.001$ compared with untreated controls. (C) KB cells were treated with $2.5 \mu \mathrm{g} / \mathrm{ml}$ of PTS2, PT, and DDP for $36 \mathrm{~h}$, stained with Annexin V/PI, and examined with flow cytometry. Data are means \pm S.D. ${ }^{* * *} P<0.001$, compared with viability of untreated cells. ${ }^{\# \# \#} P<0.001$, compared with viability of PTS2-treated cells. Results are representative of 3 independent experiments.

Many chemotherapeutic agents reportedly suppress cancer cell growth through disruption of cell cycle progression [19]. Upon cellular stress or DNA damage, these mechanisms induce cells to undergo either cellcycle arrest, activation of repair systems, or apoptotic induction. In our present study, we showed that PTS2 evidently interferes with the cell cycle in vitro (Figure 3 ), arresting cells at $G_{1}$ phase, and thus leading them to 


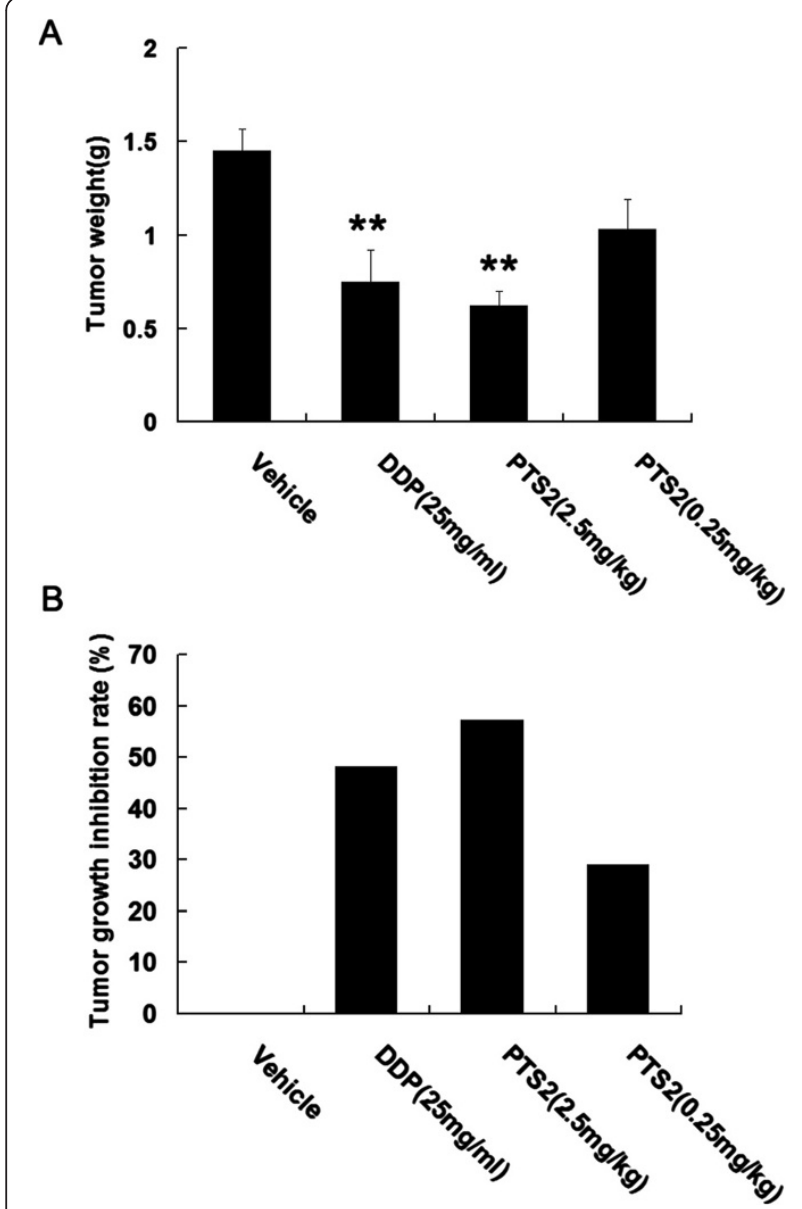

Figure 7 Inhibitory effect of PTS2 on hepatoma 22 (H22) tumors. $\mathrm{H} 22$ cells $\left(5 \times 10^{6}\right.$ cells $\left./ \mathrm{ml}\right)$ in $0.2 \mathrm{ml}$ of PBS were transplanted subcutaneously into right groins of mice; $24 \mathrm{~h}$ after tumor implantation, the mice were injected intraperitoneally with PTS2 ( 0.25 or $2.5 \mathrm{mg} / \mathrm{kg} /$ day; $\mathrm{n}=20)$, DDP $(2.5 \mathrm{mg} / \mathrm{kg} /$ day; $\mathrm{n}=10)$ or $0.2 \mathrm{ml} 0.9 \%$ saline $(n=10)$ for another 10 days. On day 11 , all the animals were killed and the tumors dissected out and weighed (A). ${ }^{*} P<0.01$ compared with controls. Tumor growth inhibition rate was calculated (B).

apoptosis. Presently, the molecular mechanisms of PTS2-induced cell cycle arrest in cancer cells require further investigation. Cells treated with PTS2 appear morphologically damaged and decreased in number (Figure 4). PTS2's apparent induction of $\mathrm{G}_{1}$ arrest and subsequent apoptosis suggest that it could be the basis of an anticancer therapy. PTS2 can also induce p53, p21 accumulation and CyclinD1 and CyclinE1 downregulation in the four tested cancer cell lines (Figure 3B).

Caspase family members, including caspases 3 and 9, are crucial effectors of apoptosis, and are cleaved during apoptosis $[19,20]$. PARP is a substrate of caspase-3; its cleavage can indicate caspase activation in response to apoptotic stimulus [21,22], and generation of cleaved caspase-3 and PARP as markers for apoptosis [23]. In analyzing the mechanism of PTS2-induced apoptosis, we found PTS2 treatment induced cleavage of caspase-9, caspase-3 and PARP in cancer cells (Figure 5), which implies that activation of caspase-9, caspase- 3 and PARP is involved in PTS2-induced cell death.

Such specific knowledge of PTS2's anticancer effects is of great benefit in antitumor therapeutic strategy. PTS2 showed both dose and time advantages in inducing cancer cell death over adriamycin (an amino-glycosidic anthracycline antibiotic) and cisplatin (a platinum compound), which suggests PTS2's potential as an anticancer drug (Figure 6). Although both PT and its derivative, PTS2, have antifungal activities [24], PT showed no obvious anticancer activity in this study.

\section{Conclusions}

Here, we report novel toxicity of PTS2 on various cancers, and show PTS2 to inhibit proliferation of four cancer cell lines and induce apoptosis involving activation of caspase-9, caspase-3 and PARP. These results suggest that PTS2 has broad-spectrum antitumor activity and could be the basis of an anticancer drug.

\section{Competing interests}

The authors declare that they have no competing interests.

\section{Authors' contributions}

YF, CL and SW carried out the experimental studies. YF and YZ drafted and completed the manuscript. YH performed the statistical analysis. JZ and LC cultured cells. $Z Y$ proofread the manuscript. XD and $Z Y$ refined the manuscript. FY and XD conceived of and designed the study. All authors read and approved the final manuscript.

\section{Acknowledgements}

We thank Professor Lan Luo for critically reading the manuscript. This work was supported by grants from the National Natural Science Foundation of China (31000632), Natural Science Foundation of Hebei Province

(C2010000409) and Educational Commission of Hebei Province (2008129). No competing financial interests exist for any of the authors.

\section{Author details}

${ }^{1}$ The Key Lab of Animal Physiology, College of Life Science, Hebei Normal University, Hebei Province, Shijiazhuang 050024, China. ${ }^{2}$ Laboratory of Medical Biotechnology, Hebei Chemical and Pharmaceutical College, Hebei Province, Shijiazhuang 050026, China. ${ }^{3}$ Jiangsu Province Key Laboratory of Molecular and Medical Biotechnology, College of Life Science, Nanjing Normal University, Nanjing 210046, China.

Received: 8 January 2013 Accepted: 14 October 2013 Published: 21 October 2013

\section{References}

1. Jang TH, Lee SJ, Woo CH, Lee K, Jeon JH, Lee DS, Choi K, Kim IG, Kim YW, Lee TJ, Park HH: Inhibition of genotoxic stress induced apoptosis by novel TATfused peptides targeting PIDDosome. Biochem Pharmacol 2012, 83:218-227.

2. Sun R, Zhang Y, Lv Q, Liu B, Jin M, Zhang W, He Q, Deng M, Liu X, Li G, Li Y, Zhou G, Xie P, Xie X, Hu J, Duan Z: Toll-like receptor 3 (TLR3) induces apoptosis via death receptors and mitochondria by up-regulating the transactivating p63 isoform alpha (TAP63alpha). J Biol Chem 2011, 286:15918-15928.

3. Servida F, Lecis D, Scavullo C, Drago C, Seneci P, Carlo-Stella C, Manzoni L, Polli E, Lambertenghi Deliliers G, Delia D, Onida F: Novel second mitochondria-derived activator of caspases (Smac) mimetic compounds sensitize human leukemic cell lines to conventional chemotherapeutic 
drug-induced and death receptor-mediated apoptosis. Invest New Drugs 2011, 29:1264-1275.

4. Fan Y, Chen H, Qiao B, Luo L, Ma H, Li H, Jiang J, Niu D, Yin Z: Opposing effects of ERK and p38 MAP kinases on HeLa cell apoptosis induced by dipyrithione. Mol Cells 2007, 23:30-38.

5. Garrido C, Galluzzi L, Brunet M, Puig PE, Didelot C, Kroemer G: Mechanisms of cytochrome c release from mitochondria. Cell Death Differ 2006, 13:1423-1433.

6. Rinner B, Li ZX, Haas H, Siegl V, Sturm S, Stuppner H, Pfragner R:

Antiproliferative and pro-apoptotic effects of Uncaria tomentosa in human medullary thyroid carcinoma cells. Anticancer Res 2009, 29:4519-4528.

7. Doose CA, Szaleniec M, Behrend P, Muller A, Jastorff B: Chromatographic behavior of pyrithiones. J Chromatogr A 2004, 1052:103-110.

8. Mann JJ, Fraker PJ: Zinc pyrithione induces apoptosis and increases expression of Bim. Apoptosis 2005, 10:369-379.

9. Kondoh M, Tasaki E, Takiguchi M, Higashimoto M, Watanabe Y, Sato M: Activation of caspase-3 in $\mathrm{HL}-60$ cells treated with pyrithione and zinc. Biol Pharm Bull 2005, 28:757-759.

10. Huang H, Pan Y, Ye Y, Gao M, Yin Z, Luo L: Dipyrithione attenuates oleic acid-induced acute lung injury. Pulm Pharmacol Ther 2011, 24:74-80.

11. Liu Z, Fan Y, Wang Y, Han C, Pan Y, Huang H, Ye Y, Luo L, Yin Z: Dipyrithione inhibits lipopolysaccharide-induced iNOS and COX-2 upregulation in macrophages and protects against endotoxic shock in mice. FEBS Lett 2008, 582:1643-1650.

12. Han C, Fu J, Liu Z, Huang H, Luo L, Yin Z: Dipyrithione inhibits IFNgamma-induced JAK/STAT1 signaling pathway activation and IP-10 /CXCL10 expression in RAW264.7 cells. Inflamm Res 2010, 59:809-816.

13. Fan $Y$, Wu D, Jin L, Yin Z: Human glutamylcysteine synthetase protects HEK293 cells against UV-induced cell death through inhibition of c-Jun NH2-terminal kinase. Cell Biol Int 2005, 29:695-702.

14. Morishita D, Takami M, Yoshikawa S, Katayama R, Sato S, Kukimoto-Niino M, Umehara T, Shirouzu M, Sekimizu K, Yokoyama S, Fujita N: Cell-permeable carboxyl-terminal p27(Kip1) peptide exhibits anti-tumor activity by inhibiting Pim-1 kinase. J Biol Chem 2011, 286:2681-2688.

15. Kiraly $R$, Demeny $M$, Fesus $L$ : Protein transamidation by transglutaminase 2 in cells: a disputed $\mathrm{Ca} 2+-$ dependent action of a multifunctional protein. FEBS J 2011, 278:4717-4739.

16. Dulic V, Kaufmann WK, Wilson SJ, Tlsty TD, Lees E, Harper JW, Elledge SJ, Reed SI: p53-dependent inhibition of cyclin-dependent kinase activities in human fibroblasts during radiation-induced G1 arrest. Cell 1994, 76:1013-1023.

17. Singh N, Nambiar D, Kale RK, Singh RP: Usnic acid inhibits growth and induces cell cycle arrest and apoptosis in human lung carcinoma A549 cells. Nutr Cancer 2013, 65(Suppl 1):36-43.

18. Gulappa T, Reddy RS, Suman S, Nyakeriga AM, Damodaran C: Molecular interplay between cdk4 and p21 dictates G0/G1 cell cycle arrest in prostate cancer cells. Cancer Lett 2013, 337:177-183.

19. Lin CH, Lu WC, Wang CW, Chan YC, Chen MK: Capsaicin induces cell cycle arrest and apoptosis in human KB cancer cells. BMC Complement Altern Med 2013, 13:46.

20. Walsh JG, Cullen SP, Sheridan C, Luthi AU, Gerner C, Martin SJ: Executioner caspase- 3 and caspase-7 are functionally distinct proteases. Proc Natl Acad Sci U S A 2008, 105:12815-12819.

21. Shao L, Guo X, Plate M, Li T, Wang Y, Ma D, Han W: CMTM5-v1 induces apoptosis in cervical carcinoma cells. Biochem Biophys Res Commun 2009, 379:866-871.

22. Rodriguez-Hernandez A, Brea-Calvo G, Fernandez-Ayala DJ, Cordero M, Navas P, Sanchez-Alcazar JA: Nuclear caspase-3 and caspase-7 activation, and poly(ADP-ribose) polymerase cleavage are early events in camptothecin-induced apoptosis. Apoptosis 2006, 11:131-139.

23. Yang C, Choy E, Hornicek FJ, Wood KB, Schwab JH, Liu X, Mankin H, Duan Z Histone deacetylase inhibitor PCl-24781 enhances chemotherapyinduced apoptosis in multidrug-resistant sarcoma cell lines. Anticancer Res 2011, 31:1115-1123.

24. Malhotra GG, Zatz JL: Investigation of nail permeation enhancement by chemical modification using water as a probe. J Pharm Sci 2002, 91:312-323.

doi:10.1186/2050-6511-14-54

Cite this article as: Fan et al:: Dipyrithione induces cell-cycle arrest and apoptosis in four cancer cell lines in vitro and inhibits tumor growth in a mouse model. BMC Pharmacology and Toxicology 2013 14:54.

\section{Submit your next manuscript to BioMed Central and take full advantage of:}

- Convenient online submission

- Thorough peer review

- No space constraints or color figure charges

- Immediate publication on acceptance

- Inclusion in PubMed, CAS, Scopus and Google Scholar

- Research which is freely available for redistribution 